\title{
PENGARUH PEMBERIAN EKSTRAK ETANOL DAUN BELIMBING WULUH (Averrhoa bilimbi L.) TERHADAP WAKTU PERDARAHAN DAN WAKTU KOAGULASI PADA MENCIT JANTAN (Mus musculus L.)
}

\author{
(THE EFFECT OF BILIMBI (Averrhoa bilimbi L.) LEAF ETHANOL EXTRACT \\ ON BLEEDING TIME AND COAGULATION TIME IN MALE MICE (Mus musculus L.))
}

\author{
I GUSTI AGUNG AYU KUSUMA WARDANI ${ }^{1}$, NI NYOMAN WAHYU UDAYANI ${ }^{1}$ \\ ${ }^{1}$ Akademi Farmasi Saraswati Denpasar, Jalan Kamboja No.11A, Denpasar, Bali
}

\begin{abstract}
Abstrak: Indonesia merupakan negara yang memiliki kekayaan hayati yang cukup besar yang dapat dikembangkan terutama untuk obat tradisional. Salah satu tumbuhan tradisional yang dapat digunakan sebagai obat yaitu belimbing wuluh (Averrhoa bilimbi L.). Tujuan penelitian ini adalah untuk mengetahui pengaruh ekstrak etanol daun belimbing wuluh terhadap waktu pendarahan dan koagulasi pada mencit. Dalam penelitian ini digunakan 24 ekor mencit sebagai sampel, yang terbagi menjadi 4 kelompok, yaitu kelompok 1 diberi aquades ad libitum (kontrol negatif); kelompok 2 diberi asetosal dosis 0,27 mg/26 g BB (kontrol positif); kelompok 3 dan 4 masing-masing diberi ekstrak etanol daun belimbing wuluh dengan dosis $200 \mathrm{mg} / \mathrm{kg} \mathrm{BB}$ dan $400 \mathrm{mg} / \mathrm{kg}$ BB. Semua perlakuan diberikan secara per oral selama 7 hari. Waktu perdarahan ditetapkan dengan metode tail bleeding, sedangkan waktu koagulasi ditetapkan dengan metode pipa kapiler. Hasil uji LSD (Least Significant Different) pada waktu perdarahan diperoleh bahwa pada kelompok kontrol positif menunjukkan ada perbedaan yang bermakna terhadap kelompok ekstrak 200 dan $400 \mathrm{mg} / \mathrm{Kg} \mathrm{BB}$, dengan nilai sig. 0,000 dan 0,001 (secara berurutan). Pada kelompok ekstrak $200 \mathrm{mg} / \mathrm{KgBB}$ menunjukkan ada perbedaan yang bermakna terhadap kelompok ekstrak $400 \mathrm{mg} / \mathrm{KgBB}$, dengan nilai sig. 0,005. Hal ini menunjukkan ekstrak $400 \mathrm{mg} / \mathrm{KgBB}$ lebih efektif dalam memperpanjang waktu perdarahan dibandingkan dengan ekstrak $200 \mathrm{mg} / \mathrm{KgBB}$. Hasil LSD waktu koagulasi pada kelompok kontrol positif menunjukkan tidak ada perbedaan yang bermakna terhadap kelompok ekstrak $400 \mathrm{mg} / \mathrm{KgBB}$, dengan nilai sig. 0,264. Pada kelompok ekstrak $200 \mathrm{mg} / \mathrm{KgBB}$ menunjukkan ada perbedaan yang bermakna terhadap kelompok ekstrak $400 \mathrm{mg} / \mathrm{KgBB}$, dengan nilai sig. 0,017. Hal ini menunjukkan ekstrak $400 \mathrm{mg} / \mathrm{KgBB}$ lebih efektif dalam memperpanjang waktu koagulasi dibandingkan dengan ekstrak $200 \mathrm{mg} / \mathrm{KgBB}$. Dari penelitian ini dapat disimpulkan bahwa kelompok ekstrak $400 \mathrm{mg} / \mathrm{KgBB}$ lebih efektif dalam memperpanjang waktu perdarahan dan koagulasi dibandingkan kelompok ekstrak $200 \mathrm{mg} / \mathrm{KgBB}$.
\end{abstract}

Kata kunci: ekstrak daun belimbing wuluh, waktu koagulasi, waktu perdarahan.

\begin{abstract}
Indonesia is a country that has considerable biological wealth that can be developed especially for traditional medicine. One of the traditional plants that can be used as a drug that is Bilimbi (Averrhoa bilimbi L.). The purpose of this study was to determine the effect of bilimbi leaf ethanol extract on bleeding time and coagulation time in mice. This research used 24 mice as samples, which is divided into 4 groups, group 1 given aquadest ad libitum (negative control); group 2 was given an aspirin dose of $0.27 \mathrm{mg} / 26 \mathrm{gBB}$ (positive control); groups 3 and 4 were each given of bilimbi leaf ethanol extract with doses of $200 \mathrm{mg} / \mathrm{kgBW}$ and $400 \mathrm{mg} / \mathrm{kgBW}$. All treatments were administered orally for 7 days. The bleeding time was determined by the tail bleeding method, while the coagulation time was determined by the capillary pipe method. The result of LSD (Least Significant Different) test at a bleeding time showed that in the positive control group there was a significant difference to the extract group of $200 \mathrm{mg} / \mathrm{KgBW}$ and $400 \mathrm{mg} / \mathrm{KgBW}$, with the sig value. 0,000 and 0.001 (respectively). In the extract group of $200 \mathrm{mg} / \mathrm{KgBW}$ showed that no significant difference to the extract group of $400 \mathrm{mg} / \mathrm{KgBW}$, with the sig value. 0.005 . This suggests that $400 \mathrm{mg} / \mathrm{KgBW}$ extract is more effective in prolonging bleeding time compared to the $200 \mathrm{mg} / \mathrm{KgBW}$ extract. The LSD of coagulation time in the positive control group showed that no significant difference to the extract group of $400 \mathrm{mg} / \mathrm{KgBW}$, with the sig value. 0.264. In the extract group of $200 \mathrm{mg} / \mathrm{KgBW}$ showed that significant difference to the extract group of $400 \mathrm{mg} / \mathrm{KgBW}$, with the sig value 0,017 . This suggests that the $400 \mathrm{mg} / \mathrm{KgBW}$ extract is more effective in prolonging the coagulation time compared to the $200 \mathrm{mg} / \mathrm{KgBW}$ extract. From this study, it can be concluded that the $400 \mathrm{mg} / \mathrm{KgBW}$ extract group is more effective in prolonging bleeding and coagulation time than the extract group $200 \mathrm{mg} / \mathrm{KgBW}$.
\end{abstract}

Keywords: bilimbi leaf extract, bleeding time, coagulation time

• email korespondensi: kusuma.wardhani21@yahoo.com 


\section{PENDAHULUAN}

Indonesia adalah negara yang kaya akan tumbuh-tumbuhan. Dalam hutan tropis Indonesia diperkirakan terdapat sekitar 30.000 jenis tumbuhan. Diduga dari jumlah tersebut sekitar 9.600 jenis diketahui berkhasiat sebagai obat dan 200 jenis diantaranya merupakan tumbuhan obat penting bagi industri obat tradisional (Sriningsih dkk., 2006).

Pemanfaatan tanaman berkhasiat obat di masyarakat terus berkembang dan diwariskan ke generasi selanjutnya. Salah satu pemanfaatan obat tradisional adalah sebagai antiplatelet. Antiplatelet merupakan agen yang digunakan untuk mencegah terjadinya agregasi platelet (Gross dan Weitz, 2009). Penggunaan obat-obatan antiagregasi platelet seperti asetosal juga digunakan untuk mencegah terjadinya agregasi platelet yang dapat membentuk sumbatan dalam pembuluh darah (Lullman, 2000). Pada pasien yang mengkonsumsi secara rutin obat golongan antikoagulan (warfarin) atau antiagregasi platelet (asetosal dan klopidogrel) untuk profilaksis tromboemboli, maka waktu perdarahan dan koagulasi menjadi lebih panjang (Despopoulos, 2003).

Salah satu tanaman yang memiliki aktivitas sebagai antiplatelet yaitu tanaman belimbing wuluh (Averrhoa bilimbi L.). Senyawa metabolit sekunder yang terdapat pada ekstrak daun belimbing wuluh antara lain flavonoid, saponin, triterpenoid dan tanin (Faharani, 2009). Penelitian yang telah dilakukan pada bagian kulit batang belimbing wuluh (Averrhoa bilimbi L.) menunjukkan Fraksi N-Heksana pada kulit batang belimbing wuluh (Averrhoa bilimbi L.) in vitro memiliki aktivitas antiplatelet (Lubis, 2015).

Berdasarkan penelitian tersebut, maka dilakukan penelitian mengenai pengaruh pemberian ekstrak etanol daun belimbing wuluh (Averrhoa bilimbi L.) terhadap waktu pendarahan dan koagulasi pada mencit jantan (Mus musculus L.).

\section{METODE PENELITIAN}

Rancangan Penelitian. Jenis penelitian yang digunakan adalah penelitian eksperimental dengan menggunakan metode randomized control group pretest-posttest only design.

Bahan. Bahan tanaman yang digunakan dalam penelitian ini adalah daun belimbing wuluh (Averrhoa bilimbi L.) yang didapatkan dari Desa Selabih, Kecamatan Selemadeg Barat, Tabanan, Bali. Tanaman yang didapat telah diidentifikasi oleh Lembaga Ilmu Pengetahuan Indonesia UPT Balai Konservasi Tumbuhan Kebun Raya "EKA KARYA" Bali. Bahan lain yang digunakan sebagai penunjang penelitian ini adalah asetosal sebagai kontrol positif dan aquadest sebagai kontrol negatif.

Alat. Alat-alat yang digunakan dalam penelitian ini meliputi: timbangan digital, pisau, pemotong kaca, kertas saring, pipa kapiler, stopwatch, batang pengaduk, termometer dan beaker glass.

Pembuatan Ekstrak Daun Belimbing Wuluh. Serbuk simplisia daun belimbing wuluh ditimbang 300 gram dan dimaserasi menggunakan $1.500 \mathrm{~mL}$ pelarut etanol $80 \%$ dalam bejana tertutup rapat dan terlindung dari cahaya. Maserat diaduk konstan selama 60 menit menggunakan batang pengaduk. Hari kedua, maserat diaduk lagi selama 60 menit, ditutup dan disimpan kembali. Hari ketiga, maserat disaring dengan corong Buchner (vakum) sehingga diperoleh filtrat-1. Ampas dimaserasi kembali dengan jenis dan jumlah pelarut yang sama dengan prosedur seperti di atas. Hari keenam, maserat disaring kembali untuk memperoleh filtrat-2 lalu digabung dengan filtrat-1. Filtrat diuapkan dengan rotary evaporator pada suhu $40^{\circ} \mathrm{C}$, sehingga diperoleh ekstrak kental.

Penyiapan Hewan Coba. Hewan uji yang akan digunakan dalam penelitian ini adalah mencit jantan sebanyak 24 ekor, dalam keadaan sehat, berumur 8-12 minggu dengan berat badan 17-40 gram.

Dosis Ekstrak Daun Belimbing Wuluh. Dosis ekstrak daun belimbing wuluh yang digunakan dalam penelitian ini adalah $200 \mathrm{mg} / \mathrm{kgBB}$ dan $400 \mathrm{mg} / \mathrm{kgBB}$.

Perlakuan Hewan Coba. Dalam penelitian ini mencit dibagi menjadi 4 kelompok. Kelompok I sebagai kontrol negatif diberi aqudest; kelompok II sebagai kontrol positif diberi asetosal dengan dosis $0,27 \mathrm{mg} / 26 \mathrm{gBB}$; kelompok III dan IV sebagai kelompok uji diberi ekstrak etanol daun belimbing wuluh dengan konsentrasi masing-masing $200 \mathrm{mg} / \mathrm{KgBB}$ dan 400mg/KgBB. Semua perlakuan diberikan sebanyak $0,5 \mathrm{ml}$.

Waktu Pendarahan. Untuk menentukan waktu perdarahan, mencit dimasukkan ke dalam holder. Ujung ekor mencit dibersihkan dengan alkohol $70 \%$ lalu ekor mencit dilukai dengan jarak $2 \mathrm{~cm}$ dari ujung ekor sepanjang $2 \mathrm{~mm}$ dengan pisau. Darah yang menetes diserap dengan menempelkan 
kertas saring. Diukur waktu dari darah pertama kali menetes sampai berhenti menetes pada kertas saring. Interval waktu dari tetes pertama hingga darah berhenti menetes adalah waktu perdarahan (Vogel, 2002).

Waktu Koagulasi. Untuk menguji waktu koagulasi, sampel darah diambil melalui sinus orbital menggunakan pipa kapiler (pretest dan posttest). Pipa kapiler dipatahkan sepanjang $0,5 \mathrm{~cm}$ setiap 15 detik sekali menggunakan pemotong kaca hingga diperoleh benang fibrin pada patahan pipa kapiler. Waktu koagulasi adalah waktu dari mulai darah pertama menetes hingga benang fibrin muncul pertama kali pada patahan pipa kapiler (Yulinah, dkk., 2008; Vogel, 2002). Perlakuan diberikan selama 7 hari karena pada penelitian pendahuluan (Astuti, 2011) diketahui bahwa peningkatan waktu koagulasi pada mencit terjadi pada hari ke-7.

Pengolahan data. Data yang diperoleh dianalisis dengan menggunakan program statistika metode SPSS ver.16. Untuk mengetahui sebaran data normal atau tidak, dilakukan uji normalitas dengan menggunakan uji Shapiro-Wilk. Uji homogenitas menggunakan test of homogeneity of variance. Selanjutnya dilakukan uji LSD (Least Significant Different) untuk mengetahui perbedaan antar kelompok perlakuan.

\section{HASIL DAN PEMBAHASAN}

Pada penelitian ini digunakan daun belimbing wuluh karena dari uji fitokimia yang telah dilakukan, daun ini mengandung metabolit sekunder yaitu flavonoid, saponin, dan tanin yang memiliki efek hemostatik.

\section{Waktu Perdarahan}

Waktu perdarahan diamati untuk melihat pengaruh bahan uji terhadap pembentukan sumbat hemostatik sementara yaitu hemostatik fase platelet. Waktu perdarahan diamati dari tetesan pertama sampai darah berhenti menetes dalam detik (Vogel, 2002). Adanya efek ditunjukkan oleh waktu perdarahan yang semakin panjang setelah pemberiaan bahan uji. Adapun hasil rata-rata waktu perdarahan pretest dan posttest dari ekstrak daun belimbing wuluh dapat dilihat pada Gambar 1.

\section{Waktu Perdarahan}

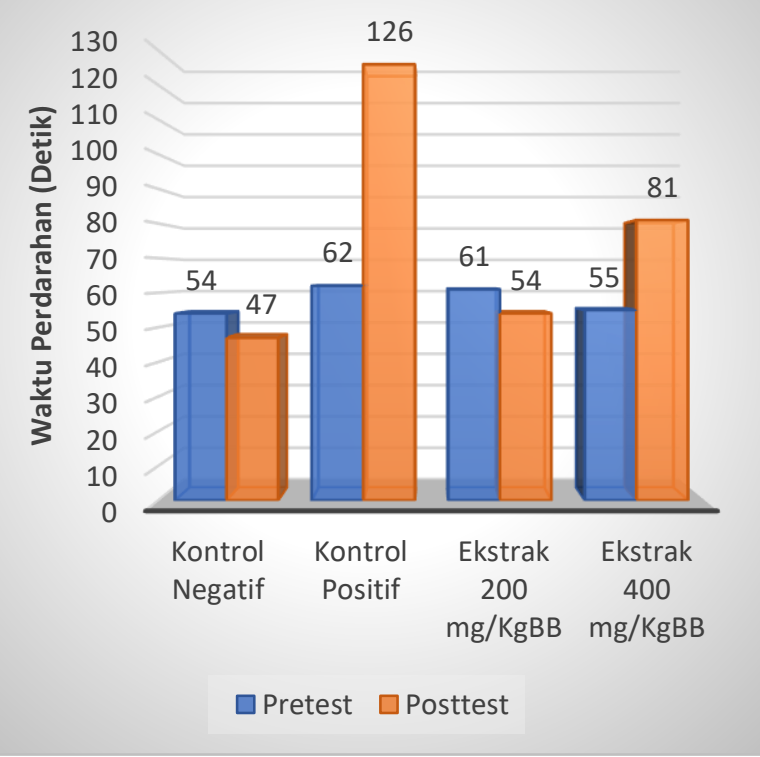

Gambar 1. Hasil rata-rata waktu perdarahan pretest dan posttest pada masing-masing kelompok

Gambar 1 menunjukkan bahwa pada kelompok kontrol negatif dan ekstrak $200 \mathrm{mg} / \mathrm{kgBB}$ terjadi penurunan rata-rata waktu perdarahan, dari 54 detik menjadi 46,6 detik (pada kontrol negatif) dan dari 61,1 detik menjadi 53,8 detik (pada ekstrak 200mg/KgBB). Penurunan waktu perdarahan yang terjadi kemungkinan disebabkan oleh keadaan lingkungan yang membuat mencit stres. Keadaan stress tersebut dapat meningkatkan hormon kortisol, dan dapat menurunkan waktu perdarahan. Selain itu stresor dapat menyebabkan menurunnya prostaglandin, sehingga meningkatkan agregasi trombosit yang mengakibatkan semakin cepatnya waktu perdarahan (Maryati, 2005). Pada kontrol positif dan ekstrak $400 \mathrm{mg} / \mathrm{kgBB}$ menujukkan terjadinya peningkatan rata-rata waktu perdarahan yaitu dari 62,1 detik menjadi 126 detik (pada kontrol positif) dan dari 55,1 detik menjadi 81 detik (pada ekstrak $400 \mathrm{mg} / \mathrm{KgBB}$ ).

Peningkatan waktu perdarahan pada ekstrak $400 \mathrm{mg} / \mathrm{KgBB}$ diduga karena adanya kandungan metabolit sekunder pada ekstrak etanol daun belimbing wuluh yaitu flavonoid. Flavonoid mampu menghambat pelepasan mediator asam arakidonat yang menyebabkan tromboksan A2 tidak terbentuk sehingga tidak mampu mengaktivasi platelet untuk beragregasi (Middleton, 2000; Morimitsu et al., 2000). 


\section{Analisis statistik}

Waktu perdarahan diuji normalitasnya dengan menggunakan uji Shapiro-Wilk. Hasil analisis menunjukkan bahwa data terdistribusi normal ( $p>0,05)$. Pengujian dilanjutkan dengan uji homogenitas atau keragaman data menggunakan test of homogeneity of variance. Melalui tes ini diperoleh bahwa data mempunyai ragam yang homogen dengan nilai signifikansi $0,88(\mathrm{p}>0,05)$.

Hasil uji LSD dari masing-masing kelompok dapat dilihat pada tabel 1. Pada kelompok kontrol negatif dengan kelompok ekstrak $200 \mathrm{mg} / \mathrm{Kg} \mathrm{BB}$, diperoleh nilai sig. 1,000 ( $>>0,005)$. Hal ini menunjukkan efektivitas ekstrak ekstrak $200 \mathrm{mg} / \mathrm{KgBB}$ tidak berbeda bermakna dengan kontrol negatif dalam memperpanjang waktu perdarahan. Pada kelompok kontrol positif menunjukkan ada perbedaan yang bermakna terhadap kelompok ekstrak $200 \mathrm{mg} / \mathrm{KgBB}$ dan $400 \mathrm{mg} / \mathrm{KgBB}$, dengan nilai sig. 0,000 dan 0,001 (secara berurutan). Hal ini menunjukkan kontrol positif lebih efektif dalam memperpanjang waktu perdarahan dibandingkan dengan ekstrak $200 \mathrm{mg} / \mathrm{KgBB}$ dan $400 \mathrm{mg} / \mathrm{KgBB}$. Pada kelompok ekstrak 200mg/KgBB menunjukkan ada perbedaan yang bermakna terhadap kelompok ekstrak $400 \mathrm{mg} / \mathrm{KgBB}$, dengan nilai sig. 0,005. Hal ini menunjukkan ekstrak 400mg/KgBB lebih efektif dalam memperpanjang waktu perdarahan dibandingkan dengan ekstrak 200mg/KgBB.

Tabel 1. Hasil perbandingan selisih waktu perdarahan pada pretest dan posttest masingmasing kelompok

\begin{tabular}{|c|c|c|c|}
\hline \multicolumn{2}{|c|}{ Kelompok Perbandingan } & Sig. & Keterangan \\
\hline \multirow{3}{*}{$\begin{array}{l}\text { Kontrol } \\
\text { negatif }\end{array}$} & Kontrol positif & 0,000 & $\begin{array}{l}\text { Ada perbedaan } \\
\text { signifikan }\end{array}$ \\
\hline & $\begin{array}{l}\text { Ekstrak } 200 \\
\mathrm{mg} / \mathrm{KbBB}\end{array}$ & 1,000 & $\begin{array}{l}\text { Tidak ada perbedaan } \\
\text { signifikan }\end{array}$ \\
\hline & $\begin{array}{l}\text { Ekstrak } 400 \\
\mathrm{mg} / \mathrm{KbBB}\end{array}$ & 0,005 & $\begin{array}{l}\text { Ada perbedaan } \\
\text { signifikan }\end{array}$ \\
\hline \multirow{3}{*}{$\begin{array}{l}\text { Kontrol } \\
\text { positif }\end{array}$} & $\begin{array}{l}\text { Kontrol } \\
\text { negatif }\end{array}$ & 0,000 & $\begin{array}{l}\text { Ada perbedaan } \\
\text { signifikan }\end{array}$ \\
\hline & $\begin{array}{l}\text { Ekstrak } 200 \\
\mathrm{mg} / \mathrm{KbBB}\end{array}$ & 0,000 & $\begin{array}{l}\text { Ada perbedaan yang } \\
\text { signifikan }\end{array}$ \\
\hline & $\begin{array}{l}\text { Ekstrak } 400 \\
\mathrm{mg} / \mathrm{KbBB}\end{array}$ & 0,001 & $\begin{array}{l}\text { Ada perbedaan } \\
\text { signifikan }\end{array}$ \\
\hline \multirow{3}{*}{$\begin{array}{l}\text { Ekstrak } \\
\text { 200mg/KgBB }\end{array}$} & $\begin{array}{l}\text { Kontrol } \\
\text { negatif }\end{array}$ & 1,000 & $\begin{array}{l}\text { Tidak ada perbedaan } \\
\text { signifikan }\end{array}$ \\
\hline & Kobtril positif & 0,000 & $\begin{array}{l}\text { Ada perbedaan } \\
\text { signifikan }\end{array}$ \\
\hline & $\begin{array}{l}\text { Ekstrak } 400 \\
\mathrm{mg} / \mathrm{KbBB}\end{array}$ & 0,005 & $\begin{array}{l}\text { Ada perbedaan } \\
\text { signifikan }\end{array}$ \\
\hline \multirow{3}{*}{$\begin{array}{l}\text { Ekstrak } \\
\text { 400mg/KgBB }\end{array}$} & $\begin{array}{l}\text { Kontrol } \\
\text { negatif }\end{array}$ & 0,005 & $\begin{array}{l}\text { Ada perbedaan } \\
\text { signifikan }\end{array}$ \\
\hline & Kobtril positif & 0,001 & $\begin{array}{l}\text { Ada perbedaan } \\
\text { signifikan }\end{array}$ \\
\hline & $\begin{array}{l}\text { Ekstrak } 200 \\
\mathrm{mg} / \mathrm{KbBB}\end{array}$ & 0,005 & $\begin{array}{l}\text { Ada perbedaan } \\
\text { signifikan }\end{array}$ \\
\hline
\end{tabular}

\section{Waktu Koagulasi}

Pengamatan pada waktu koagulasi bertujuan untuk melihat pengaruh bahan uji terhadap pembentukan sumbat hemostatik sekunder, yaitu proses hemostasis koagulasi. Pada fase koagulasi berbagai enzim dan proenzim berinteraksi. Aktivasi pada satu proenzim akan membentuk suatu enzim yang mengaktivasi proenzim kedua dan seterusnya dalam suatu reaksi yang berantai. Pada fase koagulasi menyebabkan perubahan fibrinogen yang bersikulasi menjadi fibrin yang menutup permukaan sumbatan platelet. Platelet yang diperangkap di dalam suatu struktur yang sangat berserabut membentuk suatu bekuan darah yang menutup secara efektif bagian yang terluka dari pembuluh. Adanya efek ditunjukkan oleh waktu koagulasi yang semakin panjang setelah pemberian bahan uji (Astuti, 2011). Hasil rata-rata waktu koagulasi pretest dan posttest dari ekstrak daun belimbing wuluh dapat dilihat pada Gambar 2.

\section{Waktu Koagulasi}

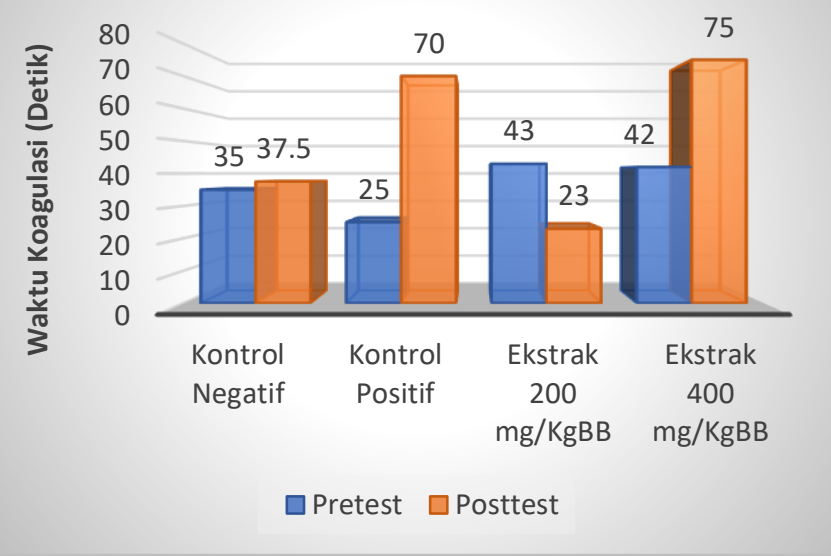

Gambar 2. Hasil rata-rata waktu koagulasi pretest dan posttest pada masing-masing kelompok

Tabel 2. Hasil perbandingan selisih waktu koagulasi pada pretest dan posttest masing-masing kelompok

\begin{tabular}{|c|c|c|c|}
\hline Kelompok & rbandingan & Sig. & Keterangan \\
\hline \multirow{3}{*}{$\begin{array}{l}\text { Kontrol } \\
\text { negatif }\end{array}$} & $\begin{array}{l}\text { Kontrol } \\
\text { positif }\end{array}$ & 0,000 & $\begin{array}{l}\text { Ada perbedaan } \\
\text { signifikan }\end{array}$ \\
\hline & $\begin{array}{l}\text { Ekstrak } 200 \\
\mathrm{mg} / \mathrm{KbBB}\end{array}$ & 0,822 & $\begin{array}{l}\text { Tidak ada } \\
\text { perbedaan } \\
\text { signifikan }\end{array}$ \\
\hline & $\begin{array}{l}\text { Ekstrak } 400 \\
\mathrm{mg} / \mathrm{KbBB}\end{array}$ & 0,010 & $\begin{array}{l}\text { Ada perbedaan } \\
\text { signifikan }\end{array}$ \\
\hline \multirow{3}{*}{$\begin{array}{l}\text { Kontrol } \\
\text { positif }\end{array}$} & $\begin{array}{l}\text { Kontrol } \\
\text { negatif }\end{array}$ & 0,000 & $\begin{array}{l}\text { Ada perbedaan } \\
\text { signifikan }\end{array}$ \\
\hline & $\begin{array}{l}\text { Ekstrak } 200 \\
\mathrm{mg} / \mathrm{KbBB}\end{array}$ & 0,001 & $\begin{array}{l}\text { Ada perbedaan } \\
\text { signifikan }\end{array}$ \\
\hline & $\begin{array}{l}\text { Ekstrak } 400 \\
\mathrm{mg} / \mathrm{KbBB}\end{array}$ & 0,264 & $\begin{array}{l}\text { Tidak ada } \\
\text { perbedaan } \\
\text { signifikan }\end{array}$ \\
\hline
\end{tabular}




\begin{tabular}{|c|c|c|c|}
\hline \multicolumn{2}{|c|}{ Kelompok Perbandingan } & \multirow{2}{*}{$\begin{array}{l}\text { Sig. } \\
0,822\end{array}$} & Keterangan \\
\hline \multirow{3}{*}{$\begin{array}{l}\text { Ekstrak } \\
200 \mathrm{mg} / \mathrm{KgBB}\end{array}$} & $\begin{array}{l}\text { Kontrol } \\
\text { negatif }\end{array}$ & & $\begin{array}{l}\text { Tidak ada } \\
\text { perbedaan } \\
\text { signifikan }\end{array}$ \\
\hline & $\begin{array}{l}\text { Kobtril } \\
\text { positif }\end{array}$ & 0,001 & $\begin{array}{l}\text { Ada perbedaan } \\
\text { signifikan }\end{array}$ \\
\hline & $\begin{array}{l}\text { Ekstrak } 400 \\
\mathrm{mg} / \mathrm{KbBB}\end{array}$ & 0,017 & $\begin{array}{l}\text { Ada perbedaan } \\
\text { signifikan }\end{array}$ \\
\hline \multirow{3}{*}{$\begin{array}{l}\text { Ekstrak } \\
\text { 400mg/KgBB }\end{array}$} & $\begin{array}{l}\text { Kontrol } \\
\text { negatif }\end{array}$ & 0,010 & $\begin{array}{l}\text { Ada perbedaan } \\
\text { signifikan }\end{array}$ \\
\hline & $\begin{array}{l}\text { Kobtril } \\
\text { positif }\end{array}$ & 0,264 & $\begin{array}{l}\text { Tidak ada } \\
\text { perbedaan } \\
\text { signifikan }\end{array}$ \\
\hline & $\begin{array}{l}\text { Ekstrak } 200 \\
\mathrm{mg} / \mathrm{KbBB}\end{array}$ & 0,017 & $\begin{array}{l}\text { Ada perbedaan } \\
\text { signifikan }\end{array}$ \\
\hline
\end{tabular}

Berdasarkan tabel di atas didapatkan data bahwa peningkatan rata-rata waktu koagulasi yang paling tinggi terjadi pada kelompok kontrol positif yaitu dari 25 detik menjadi 70 detik. Pada kelompok ekstrak $400 \mathrm{mg} / \mathrm{KgBB}$ juga terjadi peningkatan waktu koagulasi namun lebih rendah dibandingkan dengan kelompok kontrol positif yaitu dari 42,5 detik menjadi 75 detik. Peningkatan waktu koagulasi pada kelompok kontrol negatif terjadi selama 2,5 detik. Hal ini disebabkan karena mencit dapat mengadakan proses hemostatis sendiri sesuai kemampuan hemostatis tubuh mencit tanpa bantuan zat hemostatik lain (Mahmuddin, 2015). Pada kelompok ekstrak $200 \mathrm{mg} / \mathrm{KgBB}$ terjadi penurunan waktu perdarahan yaitu selama 20 detik.

Ekstrak belimbing wuluh dapat memperpanjang waktu koagulasi karena adanya senyawa metabolit sekunder seperti flavonoid. Flavonoid dapat menghambat interleukin 1 yang menginduksi faktor jaringan yang merupakan faktor ekstrinsik dalam mekanisme pembekuan darah. Penghambatan terhadap faktor jaringan menyebabkan proses koagulasi akan terhambat (Guglimone et al., 2002).

Namun dari semua perlakuan, kelompok kontrol positif memberikan efek yang paling baik dengan selisih terjadinya peningkatan sebesar 45 detik hal ini dikarenakan kelompok kontrol positif yang diberikan asetosal merupakan golongan anti inflamasi nonsteroid yangdapat memperpanjang waktu perdarahan dan koagulasi melalui mekanisme inhibisi sintesis tromboksan-A2 (TXA2). Tromboksan A2 adalah penginduksi kuat terjadinya agregasi platelet. Apabila tromboksan A2 dihambat maka agregasi platelet akan terhambat sehingga menyebabkan terjadinya peningkatan waktu perdarahan dan koagulasi (Neal, 2002; Anderson, 2001).

\section{Analisis statistik}

Pada uji normalitas dan homogenitas menunjukkan data terdistrbusi normal dan homogen. Dari hasil uji LSD masing-masing kelompok menunjukkan bahwa kelompok kontrol negatif dengan kelompok ekstrak $200 \mathrm{mg} / \mathrm{KgBB}$, diperoleh nilai sig. $0,822 \quad(p>0,005)$. Hal ini menunjukkan efektivitas ekstrak $200 \mathrm{mg} / \mathrm{KgBB}$ tidak berbeda bermakna dengan kontrol negatif dalam memperpanjang waktu koagulasi. Kelompok kontrol positif menunjukkan tidak ada perbedaan yang bermakna terhadap kelompok ekstrak 400mg/KgBB, dengan nilai sig. 0,264 yang menunjukkan efektivitas kelompok kontrol positif tidak berbeda bermakna dengan ekstrak $400 \mathrm{mg} / \mathrm{KgBB}$ dalam memperpanjang waktu koagulasi. Pada kelompok ekstrak $200 \mathrm{mg} / \mathrm{KgBB}$ menunjukkan ada perbedaan yang bermakna terhadap kelompok ekstrak 400mg/KgBB, dengan nilai sig. 0,017. Hal ini menunjukkan ekstrak $400 \mathrm{mg} / \mathrm{KgBB}$ lebih efektif dalam memperpanjang waktu koagulasi dibandingkan dengan ekstrak $200 \mathrm{mg} / \mathrm{KgBB}$.

\section{SIMPULAN}

Dari hasil penelitian ini dapat disimpulkan bahwa kelompok ekstrak 400mg/KgBB lebih efektif dalam memperpanjang waktu perdarahan dan koagulasi dibandingkan kelompok ekstrak $200 \mathrm{mg} / \mathrm{KgBB}$.

\section{DAFTAR PUSTAKA}

Anderson, P.O., Knoben, J.E., and Troutman, W. G. 2001. Handbook of Clinical Drug Data. 11 Th Ed. Mc Graw Hill. New York. p. 19-20.

Astuti, K. W. 2011, Kombinasi Asetosal dan Ekstrak Buah Mengkudu (Morinda citrifolia L.) dapat Memperpanjang Waktu Perdarahan dan Koagulasi pada Mencit, Tesis, Program Pascasarjana, Universitas Udayana, Denpasar.

Despopoulos, A. and Silbernagl, S. 2003. Color Atlas of Physiology. 5th Ed. Thieme. Stuttgart. New York. p. 102-105

Faharani, G.B., 2009, Uji Aktifitas Antibakteri Daum Belimbing Wuluh Terhadap Bakteri Streptoocus Aureus dan Achercia Coli secara Bioautografi, FMIPA UI, Jakarta. 
Gross, P. L., Weitz, J. L. 2009. New Antithrombotic Drugs. Clinical Pharmacology \& Therapeutics.86: 139146.

Gugliemone, H. A., Agnese, A. M. Montaya, dan Cabrera. 2001. Anticoagulant Effect and Action Mechanism of Sulphated Flavonoids from Flaveria bidentis. Pergamon. Thrombosis Research Vol. 105:183-188

Lubis, A. R. N. 2015, Uji aktivitas in vitro antiplatelet dan antikoagulan fraksi $n$ heksana kulit batang belimbing wuluh (Averrhoa bilimbi L.). Skripsi. Fakultas farmasi, Universitas Jember, Jember.

Lullman, H., Ziegler, A., Mohr, K., and Bieger, D. 2000. Color Atlas of Pharmacology, 2nd Ed. Thieme. Stuttgart. New York. p. 142150.

Mahmuddin, Ikramullah. 2015, Efek Antiperdarahan Alga Coklat (Sargassum sp. Dan Padina sp.) pada Luka Potong Ekor Mencit (Mus Musculus) (Pilot Study), Skripsi, Fakultas kedokteran gigi, Universitas Hasanuddin, Makassar.

Maryati, C. 2005, Pengaruh Stresor Rasa Sakit Terhadap Waktu Perdarahan (Bleeding Time) Dan Jumlah Trombosit Pada Tikus Yang Dipapar Dengan Escherichia coli, Skripsi, Fakultas Kedokteran Gigi Universitas Jember.
Middleton, E., Chithan, K., Theoharis, C. T. 2000. The Effects of Plant Flavonoids on Mammalian Cells: Implications for Inflammation, Heart Disease, and Cancer. The American Society for Pharmacology and Experimental Therapeutics. 52 (4): 673-751.

Morimitsu, Y., Hayashi, K., Nakagawa, Y., Fujii, H., Horio, F., Uchida, K.., Osawa, T. 2000. Antiplatelet and Anticancer Isothiocyanates in Japanese Domestic Horseradish, Wasabi. Mechanism of Ageing Development. 116 (2-3): 125-134.

Neal, M.J. 2002.Medical Pharmacology at A Glance. 4 th Ed. Blackwell Science. Great Britain. p. 44-45.

Sriningsih dan Agung EW. 2006. Efek Protektif Pemberian Ekstrak Etanol Herba Meniran (Phyllanthus niruri L.) Terhadap Aktivitas dan Kapasitas Fagositosis Makrofag Peritoneum Tikus. Dalam: Artocarpus Media Pharmaceutica Indonesiana Vol. 6 (2). Fakultas Farmasi Universitas Surabaya.

Vogel, H.G. 2002. Drug Discovery and Evaluation: Pharmacological Assays. 2nd Ed. Springer. Berlin. 307-308.

Yulinah, E., Sigit, J.I., dan Fitriyani, N. 2008. Efek Antiagregasi Platelet Ekstrak Etanol Buah Mengkudu (Morinda citrifolia L.), Rimpang Jahe Merah (Zingiber officinale var Sunti Val) dan Kombinasinya Pada Mencit Jantan Galur Swiss Webster. JKM. Vol. 7. No.2 Februari: 130-143. 